\title{
Political Embodiments of the Hijab in Narratives of Iraqi Refugee Women in Diaspora
}

\section{Nadia Jones-Gailani}

\begin{abstract}
This article explores how young displaced Iraqi Sunni Muslim women negotiate religious identity in diaspora, and how veiling becomes an expression of a new politicised Islamic feminism. Veiling continues to be the focus of ideological debates about Islam and women's rights in the Muslim world and in the global diaspora of displaced refugees. Young refugee and migrant women find themselves at the intersection of new and old Muslim communities, secular and religious feminisms, and first- and second-generation ideals of female modesty. Based on oral histories conducted with Arab and Kurdish Sunni Iraqi women now resettled in the Toronto and Detroit areas, the article traces a new trend in grassroots religiosity among young women in diaspora. New forms of a politicised religious subjectivity, in this case through veiling, suggest that these young women actively mobilise around a religiously constituted political consciousness. As a 'speech act' wearing hijab can in part be understood as a political performance that embodies the intersections of religious and non-religious symbolism. As the article argues, it is as migrants located at the intersection of new and old imaginaries of a global Umma that these reimagined religious subjectivities are forged.
\end{abstract}

Keywords: Hijab, Muslim, diaspora

Jones-Gailani, Nadia. 2019. 'Political Embodiments of the Hijab in Narratives of Iraqi Refugee Women in Diaspora.' Gender a výzkum / Gender and Research, Vol. 20, No. 2: 84-106, http://dx.doi.org/10.13060/25706578.2019.20.2.485.

In a 2011 White Paper issued by the Air Force Research Laboratory, author Tawfik Hamid attempts to convince the reader that headscarves worn by Muslim women can be equated to a jihadist ideology and represent a form of 'passive terrorism'. Following former President Barak Obama's announcement of a national counterextremism strategy, a summit of so-called 'experts' suggested the wisdom put forth by the White Paper was 'more relevant than ever'. A self-described former Islamist and Research Fellow at the prestigious Potomac Institute for Policy Studies, Hamid argues that the USA should take steps to 'weaken the hijab phenomenon' because the 
'hijab contribute[s] to the idea of passive terrorism' and represents an implicit refusal to 'speak against or actively resist terrorism' (Hamid 2015).

This article seeks to place into context Hamid's comments by offering an alternative lens to interpret the so-called 'hijab phenomenon' so prominent in the affective geopolitical struggle centred around Muslim women's bodies. My purpose here is also to nuance a discurse that frequently presents pious women as passive victims, or at best as pawns in a global jihad. Drawing upon ethnographic research conducted over five years with Iraqi refugee and migrant women in multiple geographic contexts, I suggest that there is a complexity to the symbol of the hijab beyond its accustomed religious significance as it is embodied in North America. Not only is the hijab a religious symbol, it is also - in the words of the women that I interviewed a form of political activism against what they perceive to be the racialisation and marginalisation of Muslim women, and against a culture that sexualises and co-opts the female form. As the hijab has become a central symbol to ideological debates about Islam and women's rights - most prominently in diasporic communities in western states - it is critical that we understand the multiple meanings of veiling, especially given the growing number and diversity of displaced Muslim (and nonMuslim Arab) refugees living outside of the Arab world. Accordingly, this paper offers an analysis of the multiple meanings of veiling for young second-generation Iraqi Sunni refugee women who were resettled in Toronto and Detroit after 2003. Taking up Judith Butler and Saba Mahmood's insight that 'speech acts' can also include nonoral or textual enunciations, I argue here that the growing phenomenon of young Muslim women veiling in secular western states amounts to a bodily act in which religious and non-religious signifiers intersect to produce a new enacted identity the religious subject. Furthermore, it is only by deconstructing the multiple religious and nonreligious meanings of these signifiers that we begin to understand how 'the making of a religious subject' is realised (Butler 1993; Mahmood 2005).

\section{'Defensive Modesty'}

I first became aware of a developing trend in young Iraqi refugee women adopting the hijab following their displacement from Iraq and settlement in North America when I became embroiled in a family feud related to the practice. My father, stepmother, sister, and brother were resettled through the United Nations High Commission for Refugees (UNHCR) from Amman, Jordan, to Ontario, Canada, in 2008. Six months after they arrived and began the process of settling into Canadian life, I received a call from my father. Uncharacteristically frantic and agitated, he blurted out 'Nadia, we need you to visit. There is something you must see, and I don't know how to explain this over the phone.' A few weeks later, I visited a tense and unhappy household. As 
I entered the living room my father was pacing the floor, swearing in Arabic, while my stepmother nervously sipped weak tea with mint. When my sister emerged from her room wearing hijab, my father exploded into a furious tirade about backwardness and 'traditional' values. 'You see!', my father started yelling dramatically, 'You see what she is doing? Talk some sense into her!' At first I tried to calm him down by explaining that she was an adult and this was her decision. He angrily reacted to my defence of the hijab by shouting back, 'What is wrong with you, aren't you supposed to be some kind of feminist?'1

In the tense stillness that followed, I began to formulate the two central questions around which I have organised this article. First, why had my sister, seemingly without cause or persuasion, decided to start wearing hijab upon arriving in Canada? Second, why was being veiled and being a feminist - in my father's mind as well as in the minds of many others - considered anathema? And with regards to the latter, why can't we see the hijab as a feminist response to the multiple and imposed narratives that regulate the lives of young Muslim migrant women? These questions informed and shaped the oral history interviews I conducted with refugee and migrant Iraqi women first in temporary sites of settlement in Amman, Jordan, and then again as they settled in Toronto and Detroit. From the sample of over one hundred oral histories collected with a diverse cross-section of Iraqi diasporic women between 2008 and 2012, I draw primarily in this article on the narratives of seven young women who started to wear hijab less than two years after arriving in North America. From the overall sample of sixty-eight women aged 18 to 29 years, thirty-eight of these

1 Interview with the author, Hamilton (Ontario), 10 June 2009. Family members identified in this paper have kindly agreed to be named in my research, and they continue to support my efforts within their community to promote and extend my research base. It is with gratitude and gravity that I identify them by name, as I realise that their personal and familial dialogue on the issue of veiling is largely unresolved and continues to cause generational and gendered tensions. My sister Yasmeen is the best possible ambassador for young Muslim women in diaspora, and I commend her resilience and efforts to educate the public about women and faith in Islam. This topic is one that remains controversial within the Iraqi communities in which I undertook my field research. In an effort to protect the privacy of all other women interviewed for my dissertation research, and in follow-up conversations undertaken specifically for the purposes of this article, all names and identifying information have been withheld. I do not wish to erase or silence Iraqi women from their narratives; rather I am keenly aware of the relatively small number of young veiled women in these communities, and the ease with which they could be identified. Whenever possible, I have tried to be faithful to their personal style and the manner and tone used to convey their deepest convictions about faith, and also about a political subjectivity still in the making. It is regrettable that I cannot quote them at greater length; however, given the many examples I have witnessed of 'bad gossip', I am reluctant to take liberties with their words. The more serious threat posed by identifying non-conformist women, and their connections to transmigrants or family members who continue to live in Iraq and the neighbouring region greatly outweighs the benefits that quoting the women at length might have for the purpose of this research. 
were Sunni, so the women make up seven from this larger sample. Interviews were conducted largely in the homes of women and their families, and in a few cases for the women in question in parks or outdoor spaces that afforded a measure of privacy to speak about intimate issues related to religion and the body.

I was admittedly fascinated by my sister's decision, and soon began to discover she was part of a small but growing trend amongst second-generation Iraqi Sunni-Muslim women in her age group (18 to 29 years of age), who have adopted the hijab in North America. ${ }^{2}$ In my conversations with young refugee and migrant Iraqi women, I also became aware that there was no one defining factor that marked their decision; rather, the women explained veiling as a means of protecting their reputation as unmarried women. In addition, all but one of the women immediately communicated the idea that the act of wearing hijab was a form of political statement. The hijab has for these women become a symbolic marker that reveals much about the role that it represents in these women's lives, particularly as it relates to the realisation of the political subject (Mahmood 2005). Indeed, adopting a feminist stance, these women frame their subjectivity within the context of an understanding of identity politics, whereby the female subject demarcates her corporal body as a site of her 'speech acts' or activism. In drawing these connections, these young women contribute in interesting ways to a new political imaginary in which overt religious markers articulate a membership in not just the material nation-state of the host community, but also a global Umma of Muslims connected by an imaginary of belonging. ${ }^{3}$

One of the critical concepts involved in this process of political identity-making is that of a 'defensive modesty'. There are several ways in which to identify the response of 'defensive modesty' in the words and actions of young displaced Iraqi women.

2 As I discuss in greater detail in my book manuscript (title and publication information provided on a separate page), the former aristocracy who went on to become the new middle to upper classes in the post-1958 independent Iraq were largely Sunni Arab (and later Kurdish Sunni) Muslims who had accumulated wealth and status over centuries of political hegemony, which included control over land, resources, and the governance of Iraq's provinces. The Ba'th regime (1968-2003) was predicated on the wholesale rewriting of Iraq's history in favour of a political narrative that supported the Sunni ascendancy. Outnumbered by the Shi'a community in Iraq, Saddam Husseyn threw his efforts behind a campaign of misinformation, which targeted education, culture, and the visual arts, and supported the idea that the Sunnis were the true indigenous Iraqis that could trace their ancestry to the prophet Muhammad. Educated Sunni families left in large numbers after the 2003 US invasion when they became the target of attacks by militia groups who looked to kidnap family members and extract vast amounts of money for their ransom. There continues to be a prevailing belief amongst Sunni Iraqis in diaspora that the current crisis in Iraq is the result of US interference and their support for Shi'a politicians, which has brought about a political stalemate in attempts to redraft the Constitution and move forward with reconstruction efforts. For more information, see Zubaida 1997; Preston 2003; al-Khalil 1989; Sassoon 2009.

3 For the purposes of this research, the following is a merely a sample of relevant work on the topic: Khan 2003; Moghissi 2005; Yadlin 2002. 
Readings of the Qur'an by both men and women sometimes (but not always) extol the virtue of culturally and economically determined modesty wherein strict guidelines are determined on the basis of local and national culture. Ongoing debates have given rise to critiques of a Salafist ${ }^{4}$ return to a literal veiling and seclusion of pious women (Wadud 1999). A close reading of the Qur'an certainly informed the notion of 'defensive modesty' among the young women I interviewed and thus acted as one of the key motivations behind veiling. As one participant noted, 'I use my Qur'an to defend my mind... and my hijab is to defend my body'. ${ }^{5}$ And a key factor in the pressing imaginary of needing to 'defend' modesty that was continually repeated throughout my interactions with young Iraqi migrant women was marriage.

Conversations on the topic of marrying 'well' commonly emerged in my interviews with Iraqi women and their relatives in diaspora. A widely accepted and transposed custom from Iraq, marriages arranged through networks of friends, family and 'interested parties' remain common, especially in communities of educated and previously affluent Sunni families (Aswad 1988). Living transnational lives, secondgeneration Iraqi women participate in a form of 'defensive modesty' in part so that they can 'prove' within the networked diasporic communities in which they belong that they value sexual modesty and purity. The hijabi women all in some respect framed their understanding of modesty within more orthodox and - as I understand it - Salafist interpretations of the Qur'an. Recent Iraqi migrants tend to try and marry within similar ethnic and religious families. In order to increase her marriage prospects, one woman commented that 'if we wear hijab then they will know we are good, and we will get the good men from Iraq'. ${ }^{6}$ This and other related topics in the interviews revealed how female bodies are the cultural terrain used to demarcate boundaries

4 The Salafist movement is an ultra-conservative reform movement within Sunni Islam that emerged in the second half of the 19th-century and advocated a return to the traditions of the religious ancestors of Islam. Salafism and the Salafiyya are frequently connected (erroneously, in most cases) with fundamentalist Islamic ideology, due in part to the emergence of Wahhabism in Saudi Arabia (the followers of the teachings of reformer Abd Al-Wahhab) as a later and more militant development within the movement. Religious orthodox Islamist groups connected to the outgrowth of a Political Islam (a category created by, and used mainly in, the West), are broadly Salafi in orientation, but not necessarily Wahhabi. Salafists desire a return to a pure Islam and try in their daily lives to emulate the behaviour and life of the Prophet Muhammad and his close companions, believing this should be the basis for a new socio-political order. In North America, and in the United States in particular, the media equates Salafism with various forms of radical terrorist groups advocating violence as the only way to rid Muslim countries of infidels and recreate a Muslim empire (as in the case of Daesh or ISIL). Even though Salafists are doctrinally rigid, it is essential to note that the majority of the followers are peaceful and do not in any way advocate violence and terror. For more on the Salafiyyah in North America, see Meijer 2009; Al-Rasheed 2002; Kundnani 2014.

5 Interview with the author in Dearborn (Detroit), 21 October 2009.

6 Interview with the author in Burlington (Ontario), 19 November 2009. 
between 'us' and 'them', which in this case, distinguishes virtuous women of intact reputation from those displaced refugee women who may have become tainted by immoral conduct in North America.

The policing and regulating of migrant women's bodies means that the response from the families of the respondents was varied and not always what one would expect to find. For example, I had assumed that family members - parents or grandparents in particular - might feel that a woman was better protected when wearing the hijab. However, in the case of the seven women in my oral history sample who adopted the hijab, only one family initially offered their support to the young woman in question. Six of the families responded with displays of anger and frustration, with the most vocal being male relatives who, like my father, expressed concern that wearing hijab would attract negative responses from employers, friends, family, and the general public (Barazangi 1989). Despite the fact that two of her aunts had previously adopted the headscarf decades before arriving in Canada, one of the participants who chose to veil recalled her conversation with her brother: 'How can you find a job wearing that - they will all think you are a terrorist because they do not know what this [hijab] is. ${ }^{17}$ Male relatives showed concern primarily with the family's reputation being coded as 'backward and conservative' - a phrase repeated throughout the interviews with respondents in reference to male members of their families. Fathers and brothers of the young hijabis participants also highlighted the growing dangers for devout Muslims in the United States and Canada, fearing that wearing hijab in public would put their daughters and sisters in physical danger. In an attempt to 'talk sense' into the women, female relatives most often resorted to ridicule, making hurtful comments and deriding their appearance as unattractive and overly pious. In one case, a participant noted that her mother told her she was starting to look shapeless and severe, likening her to 'black crows, like the women in the Gulf' who wear loose, black, floor-length abayas. ${ }^{9}$

How then do we explain the highly emotional responses that veiling has engendered from the parents and extended families of these women? What is it about the generational understandings of wearing hijab that appears to be so radically different between Sunni Muslims living in diaspora in comparison to those who have remained in Iraq?

The young refugee women that I interviewed were all born and partly socialised in Iraq. ${ }^{10}$ When the interviews took place between 2008 and 2012, over two-thirds of

7 Interview with the author in Mississauga (Ontario), 8 November 2009.

8 Hijabi is a term used to describe women who wear hijab.

9 Interview with the author in Southfield (Detroit), 20 October 2009.

10 From a cross section of twenty-two participants in this age category, seven women adopted the hijab shortly after arriving in Ontario or Michigan. 
this group was comprised of unmarried women (Rumbaut 2002). Having experienced traumatic disruption during their formative years owing to the devastating effects of international sanctions followed by the 2003 US invasion, these young women's lives were defined by a precarious optimism for a 'golden age' they partly remembered and partly reconstructed through the memories of their parents, aunts, and uncles. Family memories of lavish garden parties, summers away in Europe, and the exclusive privilege that came with being part of the accepted elite informed a need on the part of the women migrants to stabilise their identity and class standing in the chaos of resettlement (Dawisha 2009). Much of the anxiety of finding their place within new class structures in diaspora is informed by the difficulty most refugees face in acquiring the necessary documents or providing adequate documentation to have their credentials verified. Education - or the defined standards of educational equivalents - is an important factor in determining the socio-economic standing and potential of individuals and their families in Toronto and Detroit. Many of the firstand second-generation migrants I interviewed faced difficulty due to delays in their education that were caused by conflict and then resettlement. In addition, many who had completed studies in Iraq found their academic qualifications from Iraqi universities were not recognised, forcing them to make the difficult decision to repeat their studies, often within the same field or profession (Sassoon 2009).

By contrast, their parents' generation - the first-generation Iraqi migrants in North America - grew up in an entirely different world. Most of the women I interviewed who were between the ages of thirty and fifty-nine years of age formed a distinct 'ethclass' whose values and behavioural patterns were shaped by their membership in former aristocratic families, who, after the fall of the Hashemite monarchy in 1958, became Iraq's professional middle class (Cainkar 2009). These first-generation Iraqi women of Kurdish and Arab Sunni backgrounds were economically distinct as part of the professional middle class, sharing key cultural and social markers (class, education, professional experience), as well as having spent a significant portion of their adult lives living and working in Baghdad (Batatu 1979). In addition, over two-thirds of the first-generation group had previously left Iraq as students to study outside of the Middle East. During the so-called 'golden years' of economic expansion in Iraq, the Ba'th government funded thousands of students to complete professional degrees in the United Kingdom, Western Europe, North America, and Australia, on the understanding that upon the completion of their studies they would return to Iraq (Salbi, Becklund 2005; Yousif 2008). Although designed primarily for men, women often accompanied brothers and husbands in order to take advantage of the government-funded programme. ${ }^{11}$ This moment in the lives

11 Interview with the author in Mississauga (Ontario), 8 November 2008. 
of these young men and women permitted a freedom of movement, intellectual pursuit, and even a loosening of the rigid boundaries that regulated male-female intimacies. This freedom of mobility accompanied a desire by Saddam Hussein's regime to establish Iraq's reputation as a secular and progressive rising power. Young adults from privileged Sunni families - my own included - took advantage of the scheme to explore life outside of Iraq, and some even formed romantic attachments that contributed in interesting ways to the growing diaspora of Iraqis (Al-Ali 2007; Al-Jawaheri 2008). In conversations with Iraqi first-generation women, it became apparent that this encounter with the West at a formative age had profound influences on the cultural ideals of a professional Sunni and formerly political-elite class.

Born into a period of prosperity in Iraq, these women witnessed a boom in jobs that accompanied the growth in infrastructure and development. Whereas other countries in the region looked outside the nation to expand their workforce, the $\mathrm{Ba}$ 'th administration looked within, drawing upon the growing number of universityeducated female graduates in the fields of engineering, applied science, and medicine (Al-Ali 2005; Wright 2014). By the 1980s, Iraqi women were some of the most educated women in the region, and they were encouraged by the government to participate in the public sphere and in the development of an independent Iraqi nation. Professional women embraced the state's attempts to 'modernise' their lives by reforming female dress codes and improving women's legal rights. However, following a period of instability and sanctions that spanned a decade and a half, the ensuing inflation and deterioration of the state infrastructure, including funding for daycare services, forced many of these women back into the home to contend with the growing anger and frustration of male family members who were watching the rapid deterioration of their professional conditions, wages, and quality of life (Al-Ali 2005).

After the 2003 US invasion, the Arab and Kurdish Sunni professional class was displaced following the complete breakdown in security and ongoing threats against their lives. These first-generation women are in many cases experiencing living in western states for the second time in their lives, whereas twelve of the women (30 to 59 years) have degrees from western universities. During the 1970s, Iraqis were welcomed as international students, whereas now they feel prejudice growing in the United States and Canada against refugees from the Middle East. Many of their worst experiences can be equated with the spectacular rise of Islamophobia and racist attacks on Muslims, causing many in this group to fear for the safety of their children. Baffled by the ignorance of Muslim beliefs and practices, the women told stories of angry and racist encounters that have led them to hide their faith. As one participant noted: 'When I lived with my husband in Indianapolis in the late sixties, 
we had Christian, Jewish, communist friends - no one cared. Now I feel like I have to hide my faith or people will think I'm a terrorist. ${ }^{\prime 12}$

On the topic of wearing hijab in diaspora, these first-generation women had very strong opinions about what they almost exclusively viewed as recent conservative Islamic trends in Iraq. During the 1940s and 1950s, reforms to female dress codes were introduced that urged women to stop wearing the traditional floor-length black abaya in public (Al-Wardi 1965). By the late 1960s, first-generation women claim it was common to see young women sporting mini-skirts in public (Al-Ali 2007). There were only a few women from the first-generation participant group who wore hijab and they explained that Sunni women who veiled usually began to wear hijab later in life, after they were married with children. They view veiling as an expression of the biological stage in a woman's life and a sign that she is no longer fertile. A Sunni Arab woman from Baghdad narrated the story of how she left Iraq in 1997 with her brother and his family following her husband's death. As a widow, she felt a sense of security in being veiled, confiding that 'I didn't want to remarry, so I started to wear hijab. Then the men, they left me alone. ${ }^{\prime 13}$ Many women from the first-generation lived alone with their children, while their husbands worked from Iraq and other countries in the vicinity and sent remittances every month to support the family. A participant from Baghdad explained that after her husband went to work in Germany, she felt more secure living alone with the children when she began to wear hijab. She commented that, 'if you wear hijab there is no question that you will have a good reputation.'14

When I asked these same first-generation women if they would like their daughters to wear the headscarf, they all responded emphatically that unmarried Sunni women should not be veiled. Some of these participants noted that they would support their daughters if they decided to wear hijab, but only after they were married with children. Even as they explained the logic of this dichotomy, those women wearing hijab underscored the importance of beauty in determining how well an Iraqi woman could match up with a man in the homeland. When I asked a first-generation hijabi from Mosul what she considered to be the key factors in securing a suitable marriage partner, she responded that 'you must be beautiful, of course, and come from a good family and have a good reputation. My daughter is very beautiful and we come from a good family, so Insha'Allah, we will be successful in getting her a good husband, even though now our situation is not so good in Canada'.15 Such responses, particularly

12 Interview with the author in Mississauga (Ontario), 8 November 2008.

13 Interview with the author in Hamilton (Ontario), 9 November 2010.

14 Interview with the author in Hamilton (Ontario), 2 May 2009.

15 Interview with the author in Hamilton (Ontario), 9 November 2010. 
from first-generation veiled women, seem to indicate that they believe wearing the headscarf limits marriage prospects in diaspora, and it is therefore encouraged that young women appreciate their beauty as an asset (Al-Khayyat 1990).

Given these dynamics, why then do second-generation Iraqi refugee women adopt the hijab without any apparent previous interest in religious orthodoxy or without the support or suggestion of family members? The young women that I spoke with explained that they followed the example of Muslim women they had befriended at school or university who also wore the hijab. Upon closer inspection, I found that while their friends were most often Muslim migrant women, they were not in any of the seven examples from Iraq. A nineteen-year-old refugee from Baghdad claims to have felt pressure from her small circle of devout friends at university to be a 'good Muslim woman, and follow the true words of Allah the merciful'. ${ }^{16}$ Others suggested that the company of other women provided a forum within which to discuss both the physical and the spiritual aspects of this decision. In the case of one woman, when her friends urged her to veil, she admitted, 'I didn't know how to put on a hijab at the beginning - it was so hard! My friend, she laughed at me, and tried to show me, but really I had to practice a lot on my own!'17 With respect to the trend, then, my interviews suggest that, although families are not providing the impetus for the decision to veil, devout Muslim-American and Muslim-Canadian women are playing an important role in informing these decisions. Furthermore, as part of a growing global orthodox Islamic movement, networks of young pious women create a support structure for young Iraqi refugees outside the traditional family unit (Baldassar et al. 2007; Berns-MacGowan 1999; Aswad 1997).

As a distinct in-between group, the 'sociocultural characteristics and psychological experiences of these pre-adults are distinct' from first- and second-generation Canadian and American immigrants. These women are best described as the '1.5 generation'; neither fully Iraqi nor Canadian or American. The 'transnational' second generation is able to move between different identities and develop a sense of self 'shaped by personal, familial and organizational connections to people "back home" and at the same time in terms of race, ethnicity and nation are part of a political process that extends transnationally' (Fouron, Glick-Schiller 2002). Without the strong internal network of a community organisation, as is present, for example, in Christian orthodox Iraqi communities in Detroit, this in-between generation is vulnerable to a lack of 'access to mobility ladders', resulting in their professional stagnation and inability to maintain the socio-economic status of their parents' generation (Portes, Zhou 2002).

16 Group interview with the author in Hamilton (Ontario), 18 December 2010.

17 Interview with the author in Mississauga (Ontario), 10 December 2009. 
The position of this in-between generation of women is further complicated by the fact that they are of an age where one of the markers of transitioning into adulthood is finding a suitable marriage partner. In Iraq, endogamous marriages are arranged through their extended networks of kin, which is made easier by the fact that families tend to settle in close proximity to each other, so that several generations often live together in the old family home and provide support networks for professional women with young children, as well as unmarried or widowed women. Although men and women from several generations typically participate in the matchmaking process, it is the senior male family members who have the final say in their sons' or daughters' choice of marriage partner (Aswad 1997; Mathews, Rosner 1998). In diaspora, families cut off from these trans-generational support networks shift the burden to younger male relatives, who are pressured to mediate marriage proposals and uphold the family's reputation and social standing. Due to the short supply of available partners in the greater Toronto-area community in particular, young women rely heavily on networks of family and friends to match them with appropriate men in Iraq.

In marriage negotiations, modesty is frequently scrutinised as friends and family rely on oral testimonies (most often gossip) to produce 'evidence' in support of the woman's claims to virtue. As is true of other displaced ethno-national groups, the ever-changing situation in the homeland, in this case Iraq, holds real consequences for youth in diaspora (Grewal 2005; Dossa 2009). The growing religious conservatism in Iraq since the 2003 US invasion has focused attention back onto women's dress and their public appearance. In 2005, journalists started to report an increase in women wearing hijab in urban centres like Baghdad, seeing it as a means by which to protect their bodies from the gaze of American and Iraqi soldiers and militia, as well as from the growing number of unemployed male youth (Williams and Mohammad 2009). Six of the seven young hijabis I interviewed reported that the growing religious orthodoxy practised in Iraq since 2003 has affected their lives by increasing the frequency and fervency of gossip that shapes their reputation and that of their family. A potent force of female policing, the threat of 'bad' gossip and the spectre of immodesty for young Iraqi women increasingly controls dress, friendships, leisure time, and career path.

This increase in the policing of women's bodies both in Iraq and in diaspora has had a significant personal impact on the second-generation Iraqi women I interviewed (Abu-Lughod 2002; Khan 2006). All seven of the women in my oral history archive who adopted the hijab began wearing it in their late teens as a pointed expression of their faith and commitment to spreading the message of Islam. Conversations with these women also revealed that they were more overtly conservative in their religious beliefs than their parents. As one participant noted in 2010, 'I am proud to be a Muslim, so I would like to wear hijab to show people that I am not afraid to be 
a Muslim'.18 They referenced the perceived 'freedoms' that their mother's generation enjoyed and how these have been replaced with a growing concern about female reputation and marriage prospects. On the topic of marriage prospects in Iraq, another young participant noted that, 'if we wear hijab, then they will know we are good, and we will get the good men from Iraq'.19

Paradoxically, being perceived as 'too religious' seemed to be a label that very few Sunni middle-class families in Toronto and Detroit were willing to bear. One husband casually remarked during a group interview that he wished his wife would stop wearing hijab so that she could more easily mix with other Canadian women. In response, his wife pointedly replied: 'I won't take this scarf off for anyone. Not even you. ${ }^{20}$ As with many of the fathers and brothers of the participants that I also interviewed, this tension reveals the complexities of gendered and generational expressions of religiosity for Iraqi men and women. The men that I interviewed did not necessarily reject the hijab as a legitimate form of female piety; however, aside from a few participants, they did not support veiling outside the Muslim world because of the inherent association with 'developing' world (read uncivilised) mentalities. And although Islamic forms of sociability are in no way antithetical to democratic political and economic formations, first-generation Iraqi women also typically rejected ideas of public devotion (Haddad 1996; Khan 2002; Mernissi 1987; Mohanty 2003). This belief in private devotion is in no small part shaped by their generation's experiences of watching neighbouring Iran fall victim to a state-centred mechanism of socio-religious change (Dawisha 1984; Joseph 1991). First-generation Iraqi migrants lived through the carnage of Iraq's war with Iran, followed by the rise of the Muslim Brotherhood and the Da'wa movement in Egypt (Witteborn 2008). In addition, those first-generation participants who had lived outside of Iraq in predominantly secular and westernstyle societies found the idea of public devotion to be both a dangerous and foreign appropriation of religious performance.

\section{Making a Religious Political Subject}

Young second-generation Iraqi women also adopt the hijab as a political statement, and one that is informed by their feminist religious activism. Aware of the possible incongruent definitions of 'feminist' and 'feminism' in our cultural points of reference, I did not directly ask the women if they considered themselves to be making a feminist statement in adopting the veil unless they explicitly invoked feminism to explain their

18 Interview with the author in Hamilton (Ontario), 17 December 2010.

19 Interview with the author in Mississauga (Ontario), 9 December 2010.

20 Interview with the author in Mississauga (Ontario), 5 March 2010. 
actions. One of the seven hijabis initiated our conversation by openly declaring that she was a feminist who expressed her ideas of freedom through faith. When I asked her why she had decided to dress conservatively and adopt the hijab, she explained that she felt safer in covering her body. Also saying that she felt a sense of agency in the act of veiling her body, she insisted that I respect her message of a tolerant and equal Islam that creates equality for observant men and women. Framing her understanding of feminism through a discussion about individual choice, she argued that, by choosing to wear hijab, she has reclaimed control over her sexuality, thereby liberating herself as a woman. For this participant, her feminism - Islamic or otherwise - was about the right to choose, and it was her choice to cover her body. In her words: 'You see, it is not about safety really, because in Canada you can wear what you want. But I want you to look at me, at my eyes, and listen to my mouth when I am talking. ${ }^{21}$ Her rationale behind veiling, then, was that controlling her sexuality meant almost de-sexualising her body so that her intellectual and spiritual presence, and not her body, became the focus of attention.

Since the 1990s, scholars such as Leila Ahmed, Fatima Mernissi, and Amina Wadud have been deeply engaged with the relationship between Islam and feminism, and in the process they have worked to produce a discursive shift that brings feminist analysis to bear on Islamic thought, in a category now commonly recognised as 'Islamic feminism' (Ahmed 1993; Mernissi 1991; Wadud 2013). This convergence has been long resisted by others who promote the idea of Islamic feminism as a starting point from which to theorise the intersections of Islam and feminism (Barlas 2007). In so doing, the formulation of Islamic feminism as the necessary outcome of the intersection of Islam and gender-equality work has brought about what Dipesh Chakrabarty calls the 'triumphalist moment of modernity' (Chakrabarty 2000). However, the main problem with our understanding of a 'political modernity' is its foundation in categories and concepts whose genealogies are embedded in the intellectual and technological traditions of Europe. In order to break with this lineage, we must find alternate approaches to feminism(s) emerging from non-European cultural traditions (Ashfari 1994; Badran 2011; Moghissi 1999). Since feminism has such strong associations with political modernity, women's equality work is implicated in a hegemony that produces sameness between feminisms, whereas in the case of women displaced from the Muslim world, it is premised upon recognising the otherness of Muslim women's experiences (Seedat 2013a).

Nevertheless, post-colonial feminism has offered a continuing challenge to feminist hegemony in western societies, and third-wave feminism has opened the doors to accepting differences between women as part of the new direction of global

21 Interview with the author in Hamilton (Ontario), 17 December 2010. 
feminist activism. This by no means has ended the hegemony of the (western) feminist gaze when considering the lives and activisms of religious women. On the one hand, there continues to be a strong contingent of scholars who take Islam for granted in the application of feminist analysis to the history and current lives of women in the Arab world. By promoting the idea that consciousness of gender issues has always existed in Muslim culture, they have found a way to have a productive conversation about Islamic women's activism and lives (Barlas 2002; Kausar 2006; Kausar, Kamaruddin 1995; Wadud 1999). Whereas, on the other hand, there remains a more practical faction of feminists who admit to consciously using secular feminist methods and analysis that promote the convergence of Islam and feminism, on the grounds that pious Muslim women desire a feminist frame within which they can identify. Furthermore, this desire manifests in works on Islam and feminism in which we gain a greater appreciation for the utility of a feminist framework that reproduces differently across time and space, spreading in different ways and taking on the form of the nation-states that give it shape. Even as we consider the historical use of feminism in the colonial enterprise, the utility of feminist methods to access the activism, experiences, and spiritual lives of Muslim women cannot, or should not, be overlooked (Badran 2011). The problem of course remains that we can very well apply the notion of gender-egalitarian practices to a variety of historical contexts, but to talk about 'feminism' or 'feminist critique' is still to harken back to an idea that first emerged in the 1880s and has since then consistently been aligned with a Eurocentric model of colonial civilising practices located in non-secular parts of the world.

In fact, we can trace the most recent incarnation of this form of secular feminist hegemony in recent calls to democratise the Arab world and combat the war on terror and its dire implications for women living in target Muslim nation-states. Heightened tensions in the United States and Canada after the 9/11 attacks have meant that Muslims and non-Muslims are constantly being reminded of their differences and of the divisions between the 'civilising' missions in Arab and Muslim nations and the 'uncivilised' masses that need to be rescued from autocratic (and, assumedly, religious) regimes. How, then, can a reading of feminism be applied to analyse the equality and political subjectivity of Islamic feminist women? Fatima Seedat and others suggest that this is impossible if we continue to draw from 'an incomplete reading of feminism' (Seedat 2013b). I agree with Seedat that the feminist narrative is reductive and assumes a dominant model of assessing Muslim women's identity wherein they are by default 'othered' from the normative standard. Muslim women are not homogenous. Indeed, rather than being a useful analytical tool, the category 'Muslim women' is not helpful because it implies a sameness within the group and does not consider experiences of being displaced from Muslim-dominant homelands. 
It is yet another inaccurate implication of the standards of 'global sisterhood' so readily and uncritically embraced by certain secular third-wave feminists (Keddie 2009; Khan 2001).

Increasingly, a western media campaign of misinformation has come to identify 'the veil', with Islamism, extremism, jihadism, and, of course, the oppression of Muslim women (Haddad 2007). More than a decade of war propaganda has solidified not only the boundaries between 'us' and 'them' but has also breathed new life into the old argument that brown women need saving from brown men (Abu-Lughod 2002). For example, in spreading democratic values in Afghanistan, the campaign hinged on the need to mobilise armed forces to liberate Muslim women from degrading conditions and a regime that treated them as second-class citizens. In the case of Iraq, the American government was up against a secular enemy state, and a different rhetoric needed to be employed to convince the western allies that the invasion of Iraq was legitimate (which arguably they failed to accomplish). And yet, even by conservative estimates, the US invasion has resulted in a confluence of extremist militant groups seeking to destabilise the fractured regional governorates and to establish spheres of influence in Iraq, Syria, Yemen, Libya, Somalia - and the list goes on. In addition to a steep decline in women's literacy, education, and employment, the invasion and the subsequent US-backed al-Maliki government has had tragic results for the safety, mobility, and public participation for women in Iraq (Al-Ali 2007). Furthermore, one of the immediate and noticeable changes has been in terms of acceptable dress codes for women. As Iraqis increasingly travelled to Europe and North America to study or to vacation with family in the 1960s and 1970s, they brought back western fashions that they wore with pride on the streets of Baghdad. ${ }^{22}$ First-generation Iraqi women claimed that they felt free to show their hair, arms, legs, and shoulders whenever they were out for the evening in mixed company. The dramatic shift that occurred after 2003 brought about a new increase in hijabis on the streets of Baghdad and, perhaps more surprisingly, more women seen wearing the traditional floor-length black abaya that the state had abolished many decades earlier. Both serve as an indication that not only are women fearful for their physical security, but also that the shifting social hierarchies and political climate that initially caused the exodus of the professional Sunni class has left behind a void that has been filled by Shi'a Muslims desperate to reclaim a part in Iraq's federal apparatus. ${ }^{23}$ What is perhaps more alarming is the shift away from accepted secular forms of dress

22 Al-Ali also found evidence of women following Western fashions in the sixties, in her interviews with Iraqi women in the United States and the United Kingdom.

23 For further reading on Iraq's Shi'a population and the reconstruction of social classes following the 1958 revolution, see Nakash 2006; Eppel 1998. For a complete description of the developments of sects and economic classes in Iraq, see Batatu 1978. 
and public participation by women and towards a re-Islamisation of Iraqi society and politics due to the ongoing Iranian agenda to inform and control the newly appointed National Assembly in addition to their desire to expand their influence into regional politics following their thirty-year isolation.

In my interviews with Iraqi women, I approached discussions of feminism and feminist action in ways that were sensitive to this theorising of otherness, and I was careful not to reinforce the pre-existing imperial relationship between secular feminists and the 'others'. As someone with an Iraqi family who grew up primarily in the United Kingdom, I can identify in unexpected ways with these women who were displaced from Iraq during their formative years and now seek to find a platform for their voice in an unfamiliar place. I cannot, however, completely resist the imperial relationship that develops within the space of the interview as I recognise that my British upbringing and Canadian education overshadow my 'sameness' to these women. My position as both insider and outsider to Iraqi communities often makes me privy to the kind of sharing that implies a cultural intimacy, but at the same time manipulates difference in order to shape me into a sympathetic confidant (Anderson, Jack 1991; Bhabha 1990).

Yvonne Haddad and others have suggested that young Muslim women have appropriated a century-old view of the hijab as a symbol of solidarity and resistance to what they believe are efforts to eradicate the religion of Islam. Historically, the symbol of the hijab has been an integral part of revolutionary and anti-colonial struggle, illustrated most vividly in Algeria in the 1950s and Iran in the 1970s (Bullock 2002). From this perspective, the re-appropriation of the hijab in North America can be seen as a return to what these young women believe is an 'authentic' expression of Islam (Haddad 2007). At the same time, the hijab is a public affirmation of trust in North American systems of governance that guarantee the freedoms of religion and speech. The hijab has become an 'iconic symbol of North American Islamic identity' in the aftermath of the 9/11 attacks and the rise in Islamophobic rhetoric (Abu-Laban, Gabriel 2003).

Is it possible, then, that the broader neoliberal, imperialist agenda of liberating Muslim women's bodies is a driving force behind the renewed public performance of religiosity? During the most recent US campaigns in Afghanistan (2001) and Iraq (2003), western feminists were at the forefront of discourses calling for greater physical and sexual freedoms for Muslim women, and the tired reiteration that the ultimate liberation for Muslim women in the Arab world is from the tyranny of Muslim men. As many academics have countered, secular feminist hegemonic exceptionalism seeks to civilise these women in ways that refashion Muslim women's bodies into an acceptable form. Young Muslim women in diaspora, like those of my study, fight these attempts by connecting to growing networks of like-minded 
individuals online who converge to discuss theology, piety, fashion, and love (Agnew 2005; Baldassar, Gabaccia 2011). Are these young Iraqi women part of what Saba Mahmood has documented for Egypt, namely, a growing movement of women practising and advocating public piety, and in so doing, organising, critiquing, and advocating on behalf of religious movements connected to what many are calling an Islamic revival? And if the Islamic orthodoxy to which these women pledge their devotion is also in flux, how then do we evaluate the public piety of women forced into diaspora by war and conflict?

While I am in no way relegating religious women merely to the diaspora, nor am I implying that these are the only concerns of informants that identify as 'religious' women, there were points in common in how second-generation women of my study articulated the ideals of Islamic tradition that were important to their daily lives. The most clearly articulated force shaping their desire to be good Muslims was the experience of being 'othered' as recently settled migrants and refugees. And while this is but a small sample, my experiences of working within communities of diasporic Iraqis is that in some respect these women are drawing upon 'Islam as a powerful ideological tool of resistance'. Moghissi reminds us that, 'Indeed, in the absence of a viable, anti-racist, and leftist movement for Muslims, Islam is practically the only force that appears to effectively challenge global power structures and systems of domination' (Moghissi et al. 2009). As displaced Muslims are increasingly racialised in Canada and the USA, Moghissi and others suggest that this has increased the appeal of a political message that has been co-opted to many different ends, which includes the efforts of terrorist groups such as Da'esh who wish to see women reduced to second-class citizens (Soltanpour 2005). ${ }^{24}$

\section{Conclusion}

My conversations with Iraqi women suggested that their adopting of the hijab signifies an increasingly complex relationship with the diaspora and the Umma at large as religious political subjects. In large part, it seemed that new forms of worship and daily behaviour are being 'taught' and shared by Muslims from outside their Iraqi communities in both Detroit and Toronto. Not unlike those public meetings held in mosques that Sabah Mahmood documented in Egypt, migrant Muslim women in North America are teaching each other Islamic doctrine, 'thereby altering the historically male-centered character of mosques as well as Islamic pedagogy'

24 Some researchers have even documented the increase in teenagers from non-practising and secular Muslim families that are increasingly influenced by more religious friends into following conservative and often fundamentalist practices (Soltanpour 2005). 
(Mahmood 2005). The women's mosque movement, which has continued to grow in popularity since the 1970s, provides both a political and religious sensibility within Muslim contemporary societies (Mahmood 2005). Young Iraqi refugee women similarly ground their understanding of Islamic theology in these mosque meetinggroups, organising in secular and religious spaces (mosques, coffee shops, online blogs, Facebook, etc.) to discuss how they can challenge the stereotypes of Islamic fundamentalism by being part of an open dialogue that includes people of all ethnic, cultural, and religious backgrounds. The young women I interviewed found solace and friendship in small groups of Muslim women from a variety of socio-cultural and economic backgrounds who helped them learn the scriptures, social practices and religious dress they consider to be 'germane to the cultivation of the ideal virtuous self' (Mahmood 2005). Furthermore, as one young and outspoken participant claimed, 'I would like to gain agency back over my body - my mind is already free!'25 This desire to connect their spiritual being with the physical embodiment of a form of orthodox piety ultimately leads women to take on the veil as a means of reclaiming their bodies back from the West. And as one of these young women so casually remarked at the end of our discussion, 'Of course you can wear the hijab and be a feminist - why not? Who will tell me I cannot do this?'26

In a critique of Hamid's analysis of the hijab as a form of 'passive terrorism', Ingrid Mattson, a professor of Islamic Studies at the University of Western Ontario, pointed out that it is a garment worn by an incredibly diverse array of women, including Nobel Peace Prize recipient Malala Yousafzai. 'Is hijab any Muslim woman's headcover? Any style, any country? Because covering the head is very widely observed among Muslim women', Mattson asks. 'There is no logic here. Is Malala, who wears a hijab and was shot by the Taliban, a terrorist? There is nothing, sadly, more banal than for powerful people to tell women to take their clothes off' (Hussein 2016). Not only does Hamid accuse Muslim women of passive terrorism, he takes his argument one step further, claiming that along with fundamentalist ideology, the hijab represents an implicit refusal to 'speak against or actively resist terrorism' (Hussein 2016). And this only represents one of many examples of prevalent misguided ideas about why women choose to veil. How, then, are we to ask Muslim women in North America to trust us and integrate into our brand of multiculturalism, if our desires to see them unveiled are driven primarily by a secular-liberal assumption of Islam's patriarchal and misogynist qualities? And how much longer will we continue to replicate the colonial assumption that non-western cultures are inferior, misogynist, and that the women in these cultures need to be rescued through the agency of colonial rule? (Mahmood 2005).

25 Interview with the author, Hamilton (Ontario), 19 November 2009.

26 Interview with the author, Mississauga (Ontario), 16 October 2010. 
In tracing the multiple expressions of meaning given to the hijab by secondgeneration Iraqi women anxious to find communities of support and friendship, it is perhaps hardly surprising that the first place they find these connections is in the mosque and social groups. Finding like-minded women who also want to learn more about Islamic traditions and doctrines, these second-generation Iraqi migrant women subvert the assumptions at the core of the secular-liberal imaginary: that political struggle occurs at the level of the state, the economy, and the law. Using their bodies and religious observances as modes of political action in the public, young women adopting the hijab do not see the conflict between what most secular liberals would consider the historically distinct opponents of Islamism and secular liberalism. Perhaps this is because, as Mahmood reminds us, they are also indebted to the 'extension of the secular-liberal project itself' (Mahmood 2005), which has been pervasive in shaping the lives of the dominant political elite in Iraq. Now that this elite is part of the global diaspora, these Iraqi women have joined part of the grassroots Islamic revival movement, finding in the performance of piety a means to re-exert political, feminist, and cultural agency over their bodies.

\section{References}

Abu-Laban, Y., Gabriel, C. 2003. Selling Diversity: Immigration, Multiculturalism, Employment Equity and Globalization. Peterborough: Broadview Press.

Abu-Lughod, L. 2002. 'Do Muslim Women Really Need Saving?: Anthropological

Reflections on Cultural Relativism and its Others.' American Anthropologist, Vol. 104, No. 3: 783-790.

Agnew, V. (ed.). 2005. Diaspora, Memory, and Identity: A Search for Home. Toronto, Buffalo and London: University of Toronto Press.

Ahmed, L. 1993. Women and Gender in Islam: Historical Roots of a Modern Debate. New Haven: Yale University Press.

Al-Ali, N. S. 2007. Iraqi Women: Untold Stories from 1948 to the Present. New York, London: Zed Books.

Al-Ali, N. 2005. 'Reconstructing Gender: Iraqi Women between Dictatorship, War,

Sanctions and Occupation.' Third World Quarterly, Vol. 26, No. 4-5: 739-758.

Al-Khalil, S. 1989. Republic of Fear: The Politics of Modern Iraq. Berkeley: University of

California Press.

Al-Jawaheri, Y. H. 2008. Women in Iraq: The Gender Impact of International Sanctions.

London: Boulder.

Al-Khayyat, S. 1990. Honor and Shame: Women in Modern Iraq. London: Al-Saqi Books.

Al-Rasheed, M. 2002. A History of Saudi Arabia. London, New York: Cambridge University Press.

Al-Wardi, A. 1965. A Study of the Nature of Iraqi Society. Baghdad: Matba'at al-'Ani.

Anderson, K., Jack, D. 1991. 'Learning to Listen: Interview Techniques and Analysis.' Pp. 
11-26 in Berger Gluck, S., Patai, D. (eds.). Women's Words: The Feminist Practice of Oral History. New York: Routledge.

Aswad, B. 1997. 'Arab American Families.' Pp. 213-237 in DeGenove, M. K. (ed.). Families in a Cultural Context. Mayfield, CA: Mayfield Publishing.

Aswad, B. 1988. 'Strengths of the Arab Family for Mental Health Considerations and Therapy.' Pp. 93-101 in Ahmed, I., Gray, N. (eds.). The Arab American Family: A Resource Manual for Human Service Providers. Lansing: Eastern Michigan University and ACCESS.

Badran, M. 2011. Feminism in Islam: Secular and Religious Convergences. Oxford: OneWorld Publications.

Baldassar, L., Gabaccia, D. R. (eds.). 2011. Intimacy and Italian Migration: Gender and Domestic Lives in a Mobile World. New York: Fordham University Press.

Baldassar, L., Vellekoop Baldock, C., Wilding, R. (eds.). 2007. Families Caring Across Borders: Migration, Ageing and Transnational Caregiving. New York: Palgrave Macmillan.

Barazangi, N. H. 1989. 'Arab Muslim Identity Transmission: Parents and Youth.' Pp. 65-82 in Abu-Laban, B., Suleiman, M. W. (eds.). Arab-Americans: Continuity and Change. Belmont, Massachusetts: Association of Arab-American University Graduates, Inc.

Barlas, A. 2007. 'Keynote Address: Provincialising Feminism as a Master Narrative.' In Islamic Feminism: Current Perpectives. Finland: Centre for the Study of Culture, Race, and Ethnicity.

Barlas, A. 2002. Believing Women in Islam: Unreading Patriarchal Interpretations of the Qur'an. Karachi: SAMA.

Batatu, H. 1979. 'Class Analysis and Iraqi Society.' Arab Studies Quarterly, Vol. 1, No. 1: 230-245.

Batatu, H. 1978. The Old Social Classes and the Revolutionary Movements of Iraq: a Study of Iraq's Old Landed and Commercial Classes and of its Communists, Ba thists, and Free Officers. Princeton: Princeton University Press.

Bhabha, H. 1990. 'The Other Question: Difference, Discrimination and the Discourse of Colonialism.' Pp. 71-88 in Ferguson, R., Gever, M. et al. Out There: Marginalization and Contemporary Cultures. Cambridge, Massachusetts: MIT Press.

Bullock, K. 2002. Rethinking Muslim Women and the Veil: Challenging Historical \& Modern Stereotypes. Herndon, VA: The International Institute for Islamic Thought.

Butler, J. 1993. Bodies That Matter: On the Discursive Limits of 'Sex'. New York: Routledge.

Cainkar, L. A. 2009. Homeland Insecurity: The Arab American and Muslim Experience after 9/11. New York: Russell Sage Foundation.

Chakrabarty, D. 2000. Provincialising Europe. Princeton: Princeton University Press.

Dawisha, A. 2009. Iraq: A Political History from Independence to Occupation. Princeton, NJ: Princeton University Press.

Dawisha, A. 1984. 'Arabism and Islam in Iraq's War with Iran.' Middle Eastern Insight, Vol. 3: 32-33.

Dossa, P. 2009. Racialized Bodies, Disabling Worlds: Storied Lives of Immigrant Muslim Women. Toronto, London: University of Toronto Press. 
Eppel, M. 1998. 'The Elite, the Effendiyya, and the Growth of Nationalism and Pan Arabism in Hashemite Iraq, 1921-1958.' International Journal of Middle East Studies, Vol. 30, No. 2: 227-250.

Grewal, I. 2005. Transnational America: Feminisms, Diasporas, Neoliberalisms. Durham: Duke University Press.

Haddad, Y. 2007. 'The Post 9:11 Hijab as Icon.' Sociology of Religion, Vol. 68, No. 3: 253-267.

Haddad, Y. 1996. 'Islamic Values among American Muslims.' Pp. 1-13 in Bilge, B., Aswad, B. (eds.). Family and Gender among American Muslims: Issues facing Middle Eastern Immigrants and their Descendants. Philadelphia: Temple University Press.

Hamid, T. et al. 2015. Countering Violent Extremism: Scientific Methods and Strategies. Air Force Research Laboratory: Topical Strategic Multi-layer Assessment and Air Force Research Laboratory Multi-Disciplinary White Paper in Support of Counter Terrorism and Counter-WMD.

Hussein, M. 2016. 'U.S. Military White Paper Describes Wearing Hijab as "Passive Terrorism".' The Intercept. 23 February.

Joseph, S. 1991. 'Elite Strategies for State Building: Women, Family, Religion and the State in Iraq and Lebanon.' Pp. 176-200 in Kandiyoti, D. (ed.). Women, Islam and the State. Philadelphia: Temple University Press.

Kausar, Z. 2006. Muslim Women at the Crossroads: The Rights of Women in Islam and General Muslim Practices. Batu Caves, Selangor: Darul Ehsan Thinker's Library.

Kausar, Z, Kamaruddin, Z. (eds.). 1995. Women's Issues: Women's Perspectives. Petaling Jaya, Selangor, Malaysia: Women's Affairs Secretariat, IIUM.

Keddie, A. 2009. 'Giving Muslim Girls "A Voice": The Possibilities and Limits to Challenging Patriarchal Interpretations of Islam in one English Community.' Pedagogy, Culture and Society, Vol. 17, No. 3: 265-278.

Khan, M. 2003. 'Constructing the American Muslim Community.' Pp. 175-198 in Haddad, Y., Smith, J. I., Esposito, J. L. (eds.). Religion and Immigration: Christian, Jewish and Muslims Experiences in the United States. Walnut Creek, CA: AltaMira Press.

Khan, S. 2006. Zina, Transnational Feminism, and the Moral Regulation of Pakistani Women. Vancouver, Toronto: UBC Press.

Khan, S. 2002. Aversion and Desire: Negotiating Muslim Female Identity in the Diaspora. Toronto: Women's Press.

Khan, S. 2001. Muslim Women: Crafting a North American Identity. Tampa, Orlando, Miami: University Press of Florida.

Kundnani, A. 2014. The Muslims Are Coming!: Islamophobia, Extremism, and the Domestic War on Terror. London: Verso Books.

Mahmood, S. 2005. Politics of Piety: The Islamic Revival and the Feminist Subject. Second edition. Princeton, Oxford: Princeton University Press.

Mathews, S. H., Rosner, T. T. 1998. 'Shared Filial Responsibility: The Family as the Primary Caregiver.' Journal of Marriage and the Family, Vol. 50, No. 1: 185-195.

Meijer, R. 2009. Global Salafism: Islam's New Religious Movement. Oxford: Oxford University Press. 
Mernissi, F. 1991. Women and Islam: An Historical and Theological Enquiry. Oxford: Blackwell and Blackwell.

Mernissi, F. 1987. Beyond the Veil: Male-Female Dynamics in Modern Muslim Society. Bloomington: Indiana University Press.

Mohanty, C. T. 2003. Feminism without Borders: Decolonizing Theory, Practicing Solidarity. Durham, London: Duke University Press.

Moghissi, H., Rahnema, S., Goodman, M. J. (eds.). 2009. Diaspora by Design: Muslims in Canada and Beyond. Toronto, Buffalo, London: University of Toronto Press.

Moghissi, H. 1999. Feminism and Islamic Fundamentalism: The Limits of Postmodern Analysis. London: Zed Books.

Nakash, Y. 2006. Reaching for Power: Shi'a in Modern Arab World. Princeton, NJ: Princeton University Press.

Portes, A., Zhou, M. 2002. 'The New Second Generation: Segmented Assimilation and Its Variants.' The Annals of the American Academy of Political and Social Science, Vol. 530: 74-96.

Preston, Z. 2003. The Crystallization of the Iraqi State: Geopolitical Function and Form. Oxford, Berlin: Peter Lang.

Rumbaut, R G. 2002. 'Severed or Sustained Attachments? Language, Identity, and Imagined Communities in the Post-Immigrant Generation.' Pp. 43-95 in Levitt, P., Waters, M. C. (eds.). The Changing Face of Home: The Transnational Lives of the Second-Generation. New York: Russell Sage Foundation.

Salbi, Z, Becklund, L. 2005. Between Two Worlds, Escape from Tyranny: Growing up in the Shadow of Saddam. New York: Gotham Books.

Sassoon, J. 2009. The Iraqi Refugees: The New Crisis in the Middle East. London: I. B. Taurus.

Seedat, F. 2013a. 'Islam, Feminism, and Islamic Feminism: Between Inadequacy and Inevitability.' Journal of Feminist Studies in Religion, Vol. 29, No. 2: 25-45.

Seedat, F. 2013b. 'When Islam and Feminism Converge.' Muslim World, Vol. 103, No. 3: 404-420.

Soltanpour, S. 2005. 'Iranian-Islamic Centers in Toronto.' Part 2. Shahrvand Weekly, 11 February, 926.

Wadud, A. 1999. Qur'an and Woman: Rereading the Sacred Text from a Woman's Perspective. Oxford, New York: Oxford University Press.

Williams, T., Mohammad, A. 2009. 'What Not to Wear, Baghdad Style: Fashion Rules Begin to Change.' The New York Times, 5 June, A10.

Witteborn, S. A. 2008. 'Identity Mobilization Practices of Refugees: The Case of Iraqis in the United States and the War in Iraq.' Journal of International and Intercultural Communication, Vol. 1, No. 3: 202-220, https://doi.org/10.1080/17513050802101781.

Wright, T. 2014. 'Managing Gender Expectations upon Resettlement: The Experiences of Iraqi Kurdish Muslim Women in the UK.' Gender, Place and Culture, Vol. 21, No. 6: 733-749, https://doi.org/10.1080/0966369X.2013.802665.

Yadlin, R. 2002. 'The Muslim Diaspora in the West.' Chapter 10 in Ma'oz, M., Sheffer, G. (eds.). Middle Eastern Minorities and Diasporas. Brighton, Portland: Sussex Academic Press. 
Yousif, A. 2008. Muslims in Canada: A Question of Identity. 2nd edition. Ottawa: Legas. Zubaida, S. 1997. 'Nations: Old and New, Comments on Anthony D. Smith's 'The Myth of the "Modern Nation" and the Myths of Nations.' Paper presented to the Anthropology Seminar Series, London: University College.

@) BY-NC Nadia Jones-Gailani, 2019.

(a) BY-NC Institute of Sociology of the Czech Academy of Sciences, 2019.

Dr Nadia Jones-Gailani is Assistant Professor of Gender and History in the Gender Studies Department at Central European University in Budapest. With a focus on Muslim feminism(s) and women's political subjectivity in the Modern Arab World, her research interests are centred on individual life histories and what these can tell us about women's day-to-day experiences of war, loss, and displacement. Contact email: JonesN@ceu.edu. 